Historic, Archive Document

Do not assume content reflects current scientific knowledge, policies, or practices. 

$a$ SD II
.$A 422$

Reserve

$\approx$ United States

Department of

Timber,

Forest Pest.

\& Cooperative

Forestry

Management

Denver, Colorado

USS

Technical Report R2-42

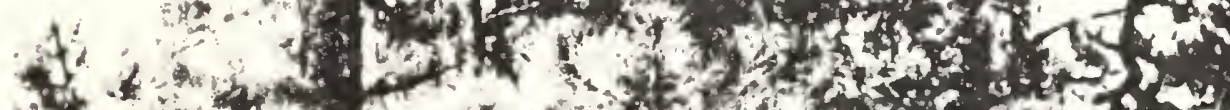

Dwarf Mistletoe

with Ethephon

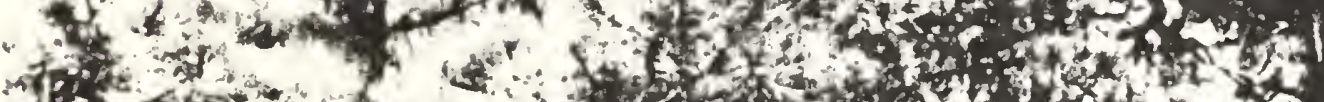

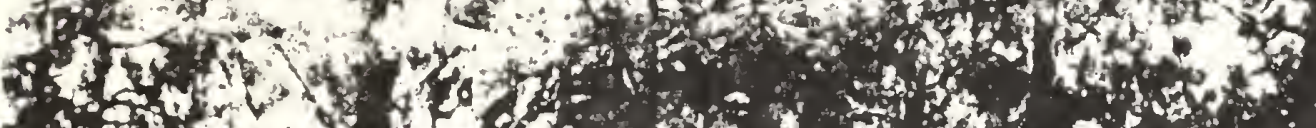

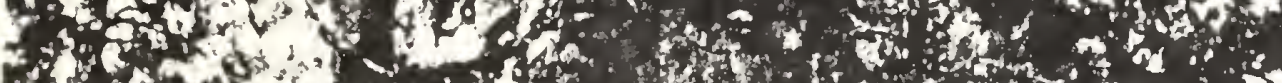

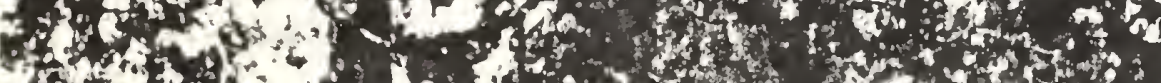

$7 f^{2}$.

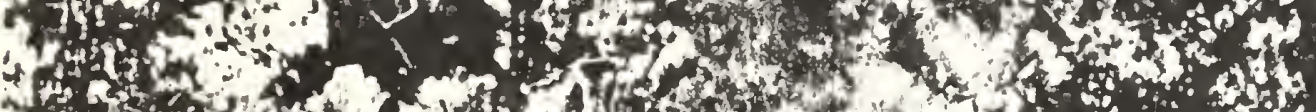

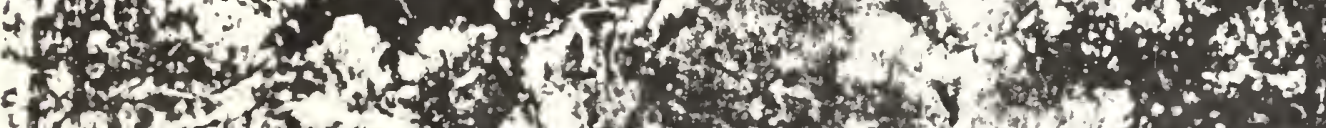

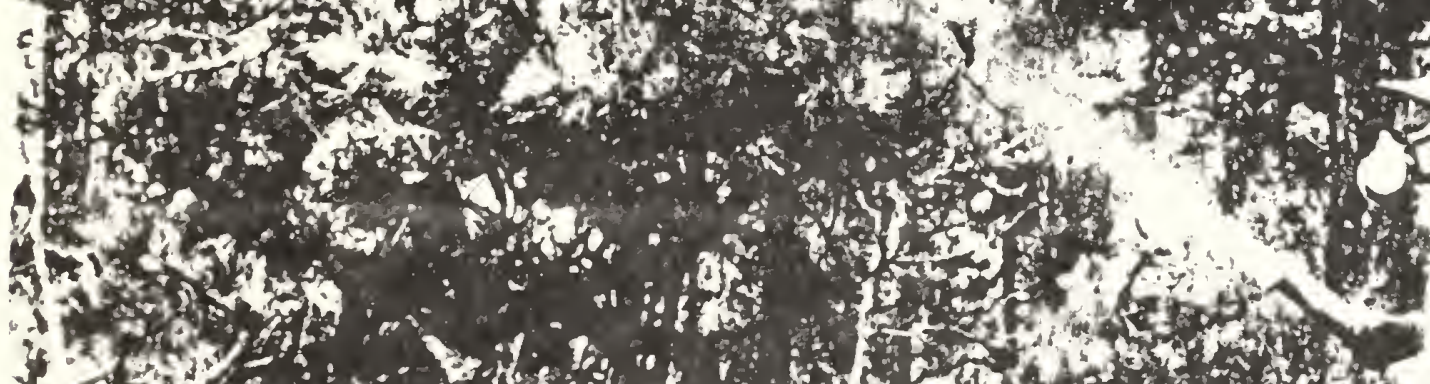

30 (3)

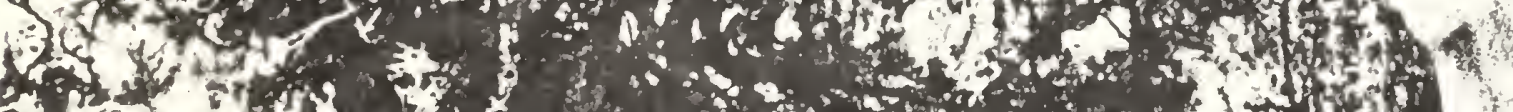

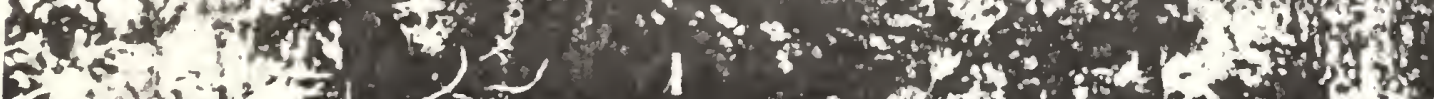

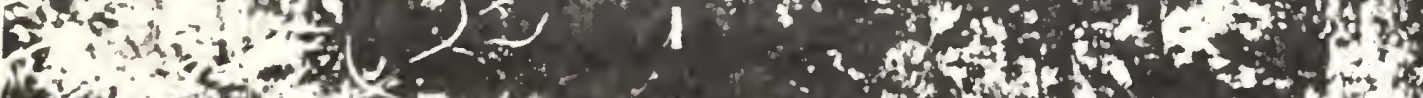

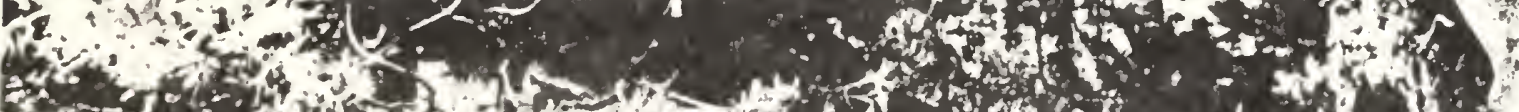

(6)

Tof ar $\therefore$ (1)

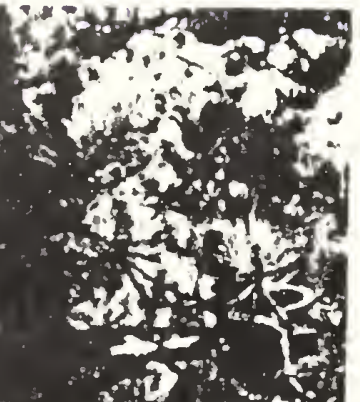
$2 x^{2}$

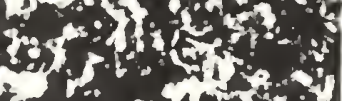
r const ond tot

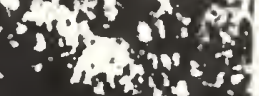

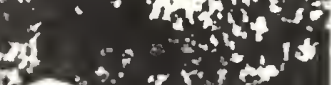




\title{
REDUCTION OF PONDEROSA PINE \\ DWARF MISTLETOE WITH \\ THE PLANT GROWTH REGULATOR ETHEPHON
}

\author{
by \\ David H. LJohnson \\ Supervisory Plant Pathologist \\ and \\ Frank G. Hawksworth \\ Research Plant Pathologist
}

Technical Report R2-42

March 1988

Timber, Forest Pest, and Cooperative Forestry Management

Rocky Mountain Region

USDA Forest Service

11177 W. 8th Avenue

Lakewood, Colorado 80225 


\section{ACKNOWLEDGMENTS}

The field assistance of Mark Reichel and John Sprackling is greatly appreciated. We also want to thank Tom Schwartz of Rhone-Poulenc Inc. for supplying the chemicals, ethephon, spreader-sticker and surfactant. 


\begin{abstract}
Previous research showed that ethephon, an ethylene-releasing plant growth regulator, induced abscission of dwarf mistletoe shoots on black spruce, lodgepole pine and ponderosa pine. During June 1987, ethephon was applied with a backpack sprayer unit (Solo Mist Blower) at the rate of $2500 \mathrm{ppm}$ plus surfactants and spreader-sticker per gallon of water to ponderosa pine infected with dwarf mistletoe (Arceuthobium vaginatum subspecies cryptopodum).

Evaluation of treated mistletoe shoots 5 weeks after treatment showed a 56 percent reduction in shoots compared to controls.
\end{abstract}

\title{
Disclaimer
}

The use of trade and company names is for the benefit of the reader; such use does not constitute an official endorsement or approval of any service or product by the U.S. Department of Agriculture to the exclusion of others that may be suitable. 



\section{INTRODUCTION}

Dwarf mistletoes are some of the most important pathogens of conifers in the United States (Johnson and Hawksworth 1985). These parasites cause mortality and reduced growth of infected trees. In the Rocky Mountain Region, it has been estimated that more than 10 million cubic feet is lost to lodgepole pine and ponderosa pine dwarf mistletoes on National Forest System lands in Colorado and Wyoming alone.

Effective silvicultural practices have been developed to reduce losses to dwarf mistletoes; however, alternative methods of control are desirable, especially for infected trees in high value stands, recreational areas and ornamental plantings around homes and cabins.

Control of dwarf mistletoes with chemicals has generally been restricted to tests using herbicides. Recent tests with growth regulators show potential for control. The ethylene that is released from certain growth regulators promotes abscission of mistletoe shoots. The plant growth regulators Ethrel $R$ and Florel $\mathrm{R}$ containing ethephon have been tested for the past few years on black spruce infected with Arceuthobium pusillum, lodgepole pine infected with A. americanum and ponderosa pine infected with $A$. vaginatum subsp. cryptopodum (Livingston et al. 1983; Livingston et al. 1985; Nicholls et al. 1986; Nicholls et al. 1987).

Ethephon is routinely used on food crops to promote abscission of leaves and fruits. As ethephon is absorbed into plant tissues, ethylene is released, causing susceptible plant parts to abscise (De Wilde 1971). Ethylene also exists naturally in conifers and is thought to be responsible for natural abscission of older dwarf mistletoe shoots.

Applications have been made with hand sprayers, hydraulic hand-jet sprayers, back-pack mist blowers and helicopters. Ground application of ethephon has resulted in mistletoe shoot abscission rates of 74 to 100 percent in lodgepole pine. In a small scale test using hand sprayers, an abscission rate of 59 percent was noted on ponderosa pine infected with $\underline{A}$. vaginatum subsp. cryptopodum in Colorado.

Since there is only limited data on the effectiveness of ethephon in controlling ponderosa pine dwarf mistletoe, the purpose of this study was to determine the effectiveness of ethephon applied with a Solo Mist Blower in reducing this mistletoe. 


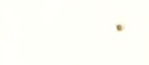


To determine the effectiveness of ethephon in causing abscission of ponderosa pine dwarf mistletoe shoots, an area of heavily infected ponderosa pine was selected on the Manitou Experimental Forest, near Woodland Park, Colorado. One treatment was evaluated: $2500 \mathrm{ppm}$ ethephon with surfactant and spreader-sticker in water and its control, surfactant and spreader-sticker alone in water.

Non-systemic infections were randomly selected in the lower crowns of pines for each treatment: 30 branch infections on 20 trees for controls and 30 infections on 15 trees for ethephon treatment. Each infection was labelled with metal tags and numbered for subsequent observation. The number of shoots on each infection was estimated and recorded. The dwarf mistletoe rating (DMR) for each tree was also determined based on the presence of infected branches. A photographic record was made of selected individual infections.

On June 30, 1987, during warm, sunny weather, ethephon was applied by Solo Mist Blowers to 15 infected pines at the rate of $2500 \mathrm{ppm}$ plus $0.1 \%$ surfactant (Spray-Aide R) and 0.1\% spreader-sticker (Nu Film 77 R). For controls, 20 infected pines were sprayed with water containing surfactant and spreader-sticker.

\section{RESULTS AND DISCUSSION}

Five weeks after treatment (August 3, 1987), the previously tagged infections and trees were evaluated. The number of mistletoe shoots was estimated as before and DMR of each tree estimated. Results before and after treatment are presented in Table 1. Statistical analysis showed that the reduction in numbers of shoots in the ethephon-treatment were significantly different than the controls at the 0.90 confidence level. Controls showed a 2.4 percent reduction, probally a result of natural abscission; whereas, ethephon-treated shoots showed a 57.9 percent reduction. Dwarf mistletoe ratings based on mistletoe shoots, not witches' brooms did not change in control trees, however, a slight reduction was noted in treated trees, from an average DMR of 5.3 to 4.1 (Table 1). No statistical analysis of DMR ratings was conducted.

It was hoped that reduction in shoots would be at least 75 percent or greater since these levels of control were achieved in previous tests with lodgepole pine dwarf mistletoe. It is thought that the poorer results may be related to the spray equipment. During the application, it was noted that the volume of spray was significantly reduced as the spray arm was raised. The spray tank is gravity fed, thus this reduced performance as the spray arm was raised. Also spray could not be applied effectively more than 20 feet into the tree crowns. In previous tests with hydraulic feed units, no application problems were experienced and spray could be applied 40 feet or more into the crowns. 
It is recommended that a similar test be conducted in 1988 with hydraulic equipment. We also intend to remeasure trees treated in 1987 in 1988 since additional losses of shoots are anticipated and to determine whether resprouting occurs on treated infections.

Previous studies have shown that ethephon does not kill the endophytic system and regrowth of dwarf mistletoe shoots occurs one to four years after ethephon-induced abscission. It is also necessary to determine when mature seeds are formed on redeveloping shoots.

Additional evaluations of ethephon are needed to determine the most effective time to apply the chemical, the best concentration for various species, the most effective surfactant to use with the chemical, the most effective means of applying the chemical, the length of time for resprouting and production of mature seed on various hosts, and the frequency of applications.

\section{REFERENCES}

De Wilde, R. C. 1971. Practical applications of (2-chloroethyl) phosphonic acid in agricultural production. Hortscience $6(4): 364-370$.

Johnson, D. W., and F. G. Hawksworth. 1985. Dwarf mistletoes. Candidates for control through cultural management. In, Insect and Disease Conditions in the United States, 1979-1983. USDA Forest Service, Gen. Tech. Rep. W0-26:48-55.

Livingston, W. H. and M. L. Brenner. 1983. Ethephon stimulates abscission of eastern dwarf mistletoe aerial shoots on black spruce. Plant Disease $67: 909-910$.

Livingston, W. H., R. A. Blanchette, M. L. Brenner, and K. J. Zuzek. 1985. Effective use of ethylene-releasing agents to prevent spread of eastern dwarf mistletoe on black spruce. Can. J. For. Res. 15:872-876.

Nicholls, T. H., L. Egeland, F. G. Hawksworth, and D. W. Johnson. 1986. Control of dwarf mistletoe with ethephon (p.78-85), In: Proc., Western Int. For. Dis. Work Conf., Sept. 8-11, 1986, Juneau, AK.

Nicholls, T. H., L. Egeland, F. G. Hawksworth, D. W. Johnson, and M. K. Robbins. 1987. Control of dwarf mistletoes with a plant growth regulator. Poster paper presented at the Symposium, Management of Subalpine Forests: Building on 50 years of Research, Technical Conference, July 6-9, 1987, Silver Creek, Colorado. USDA For. Serv. Gen. Tech. Rep. RM-149. 
Table 1. Numbers and percent reduction of dwarf mistletoe shoots and average tree dwarf mistletoe rating (DMR) of ponderosa pines before and after treatment with water/surfactant (control) compared to ethephon/surfactant (treated).

\begin{tabular}{lllllll}
\hline Treatment & \multicolumn{3}{c}{ Number of shoots } & \multicolumn{2}{c}{ DMR } \\
& Before & After & $\%$ reduction & Before & After & \% reduction \\
\hline Control & $628 \mathrm{~b}$ & $613 \mathrm{~b}$ & 2.4 & 4.6 & 4.6 & 0.0 \\
Treated & $590 \mathrm{~b}$ & $248 \mathrm{a}$ & 57.9 & 5.3 & 4.1 & 22.6 \\
\hline
\end{tabular}

*Values followed by the same letter are not significantly different at $\mathrm{P}<0.10$, as determined by ANOVA. No statistical analysis of DMR values was conducted. 


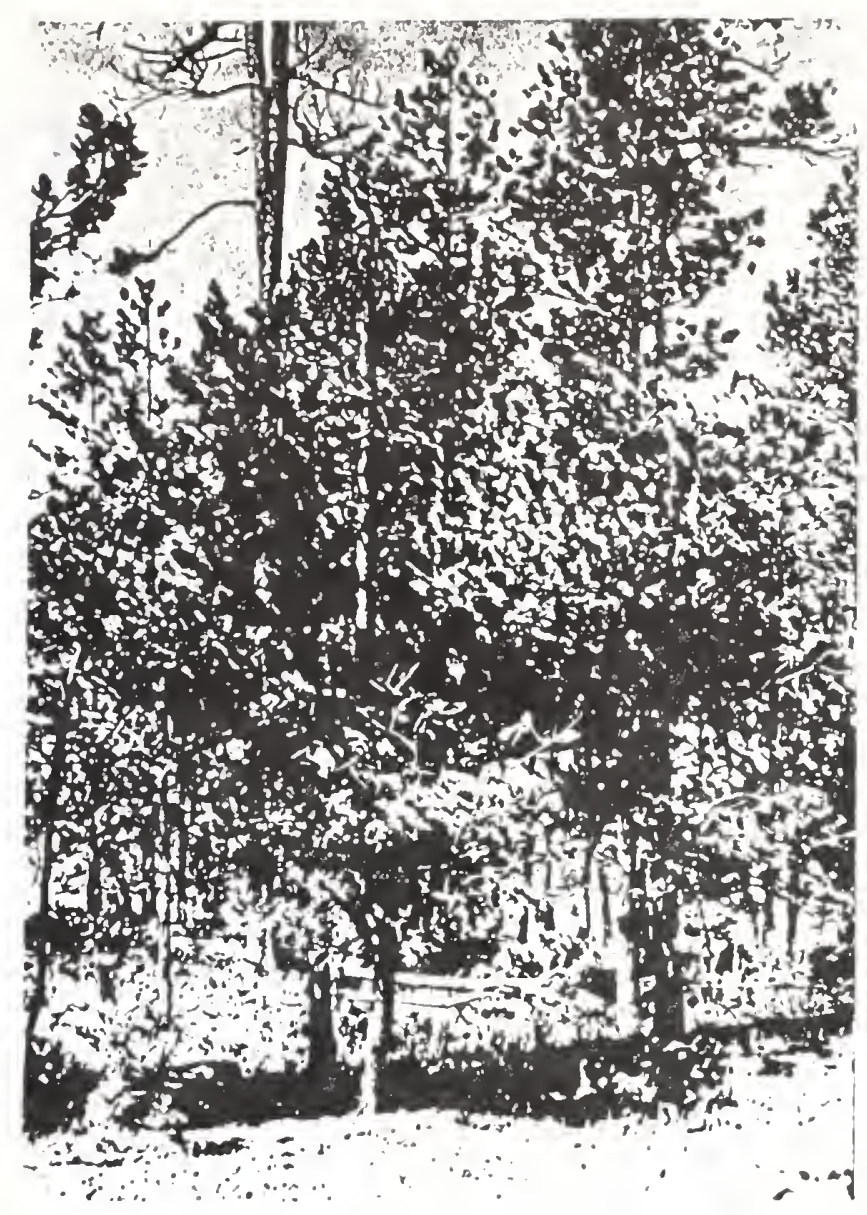

FIGURE 1. Ponderosa pine stand heavily infested with Arceuthoblum vaginatum subsp. cryptopodur, Käsitou Ezperiuental Forezt, Yocdland Par's, Colorado.

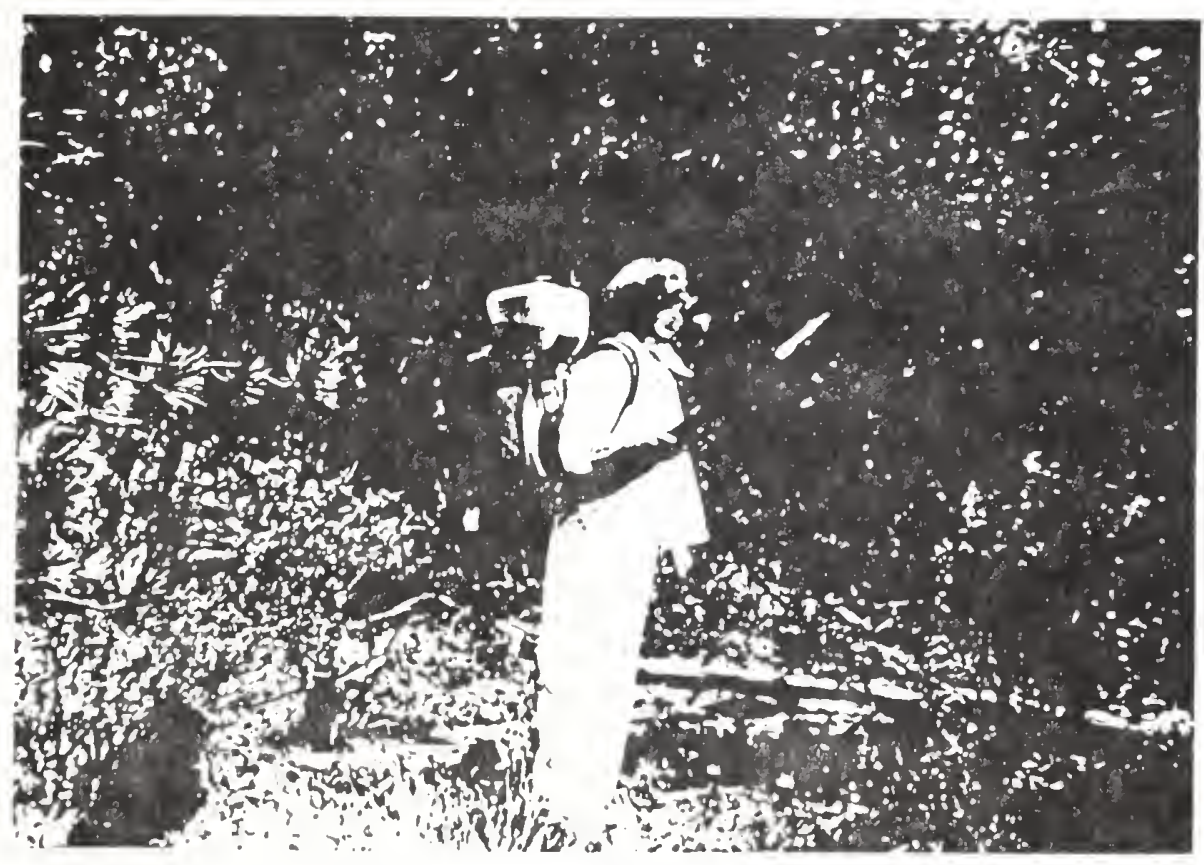

FICUR:: 2. Application of ethephon wlth a back-pack ist blower (Solo Mist Blower) Lo ponderosa pines, Manitou Experimental Forest, Colorado. 


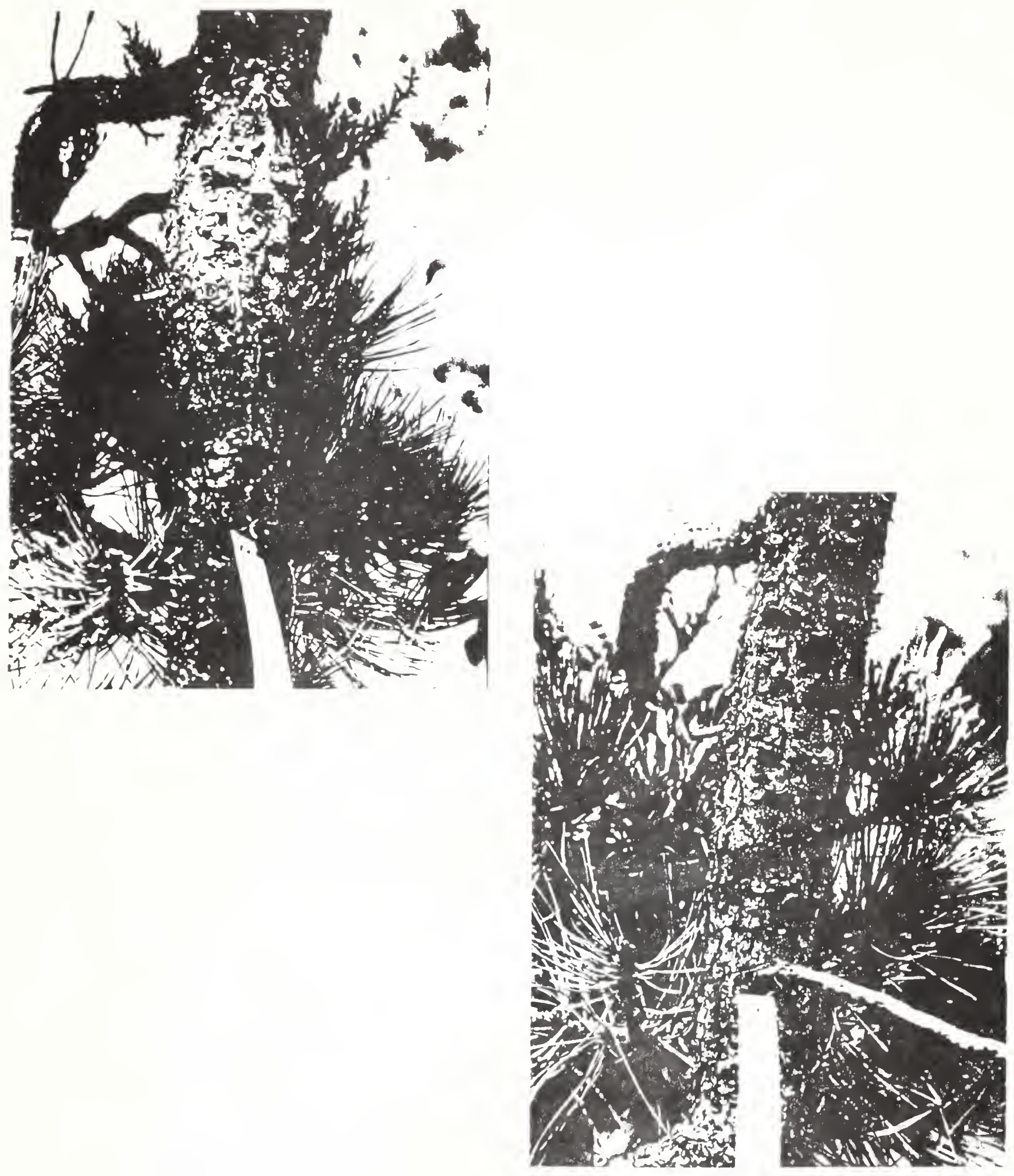

FICURE 3. Bole infection caused by ponderosa pine dwarp mistletoe before

(left) and five weeks after (right) treatment with 2500 pp ethephon. 

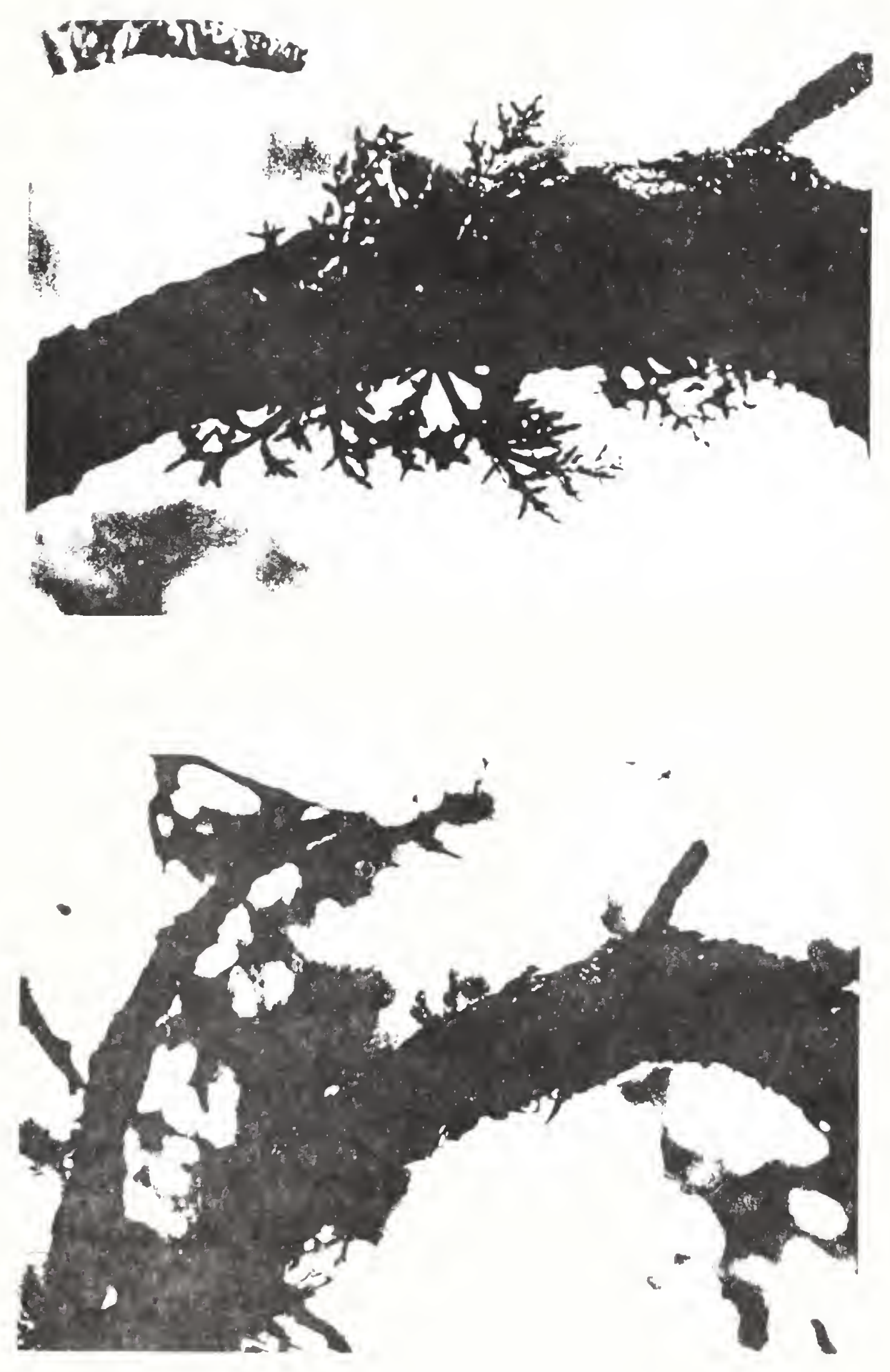

FICURE 4. Branch infection caused by ponderosa pine dwarp aistletoe before (upper) and five wecks after (lower) treatment with 2500 ppa ethephon. 


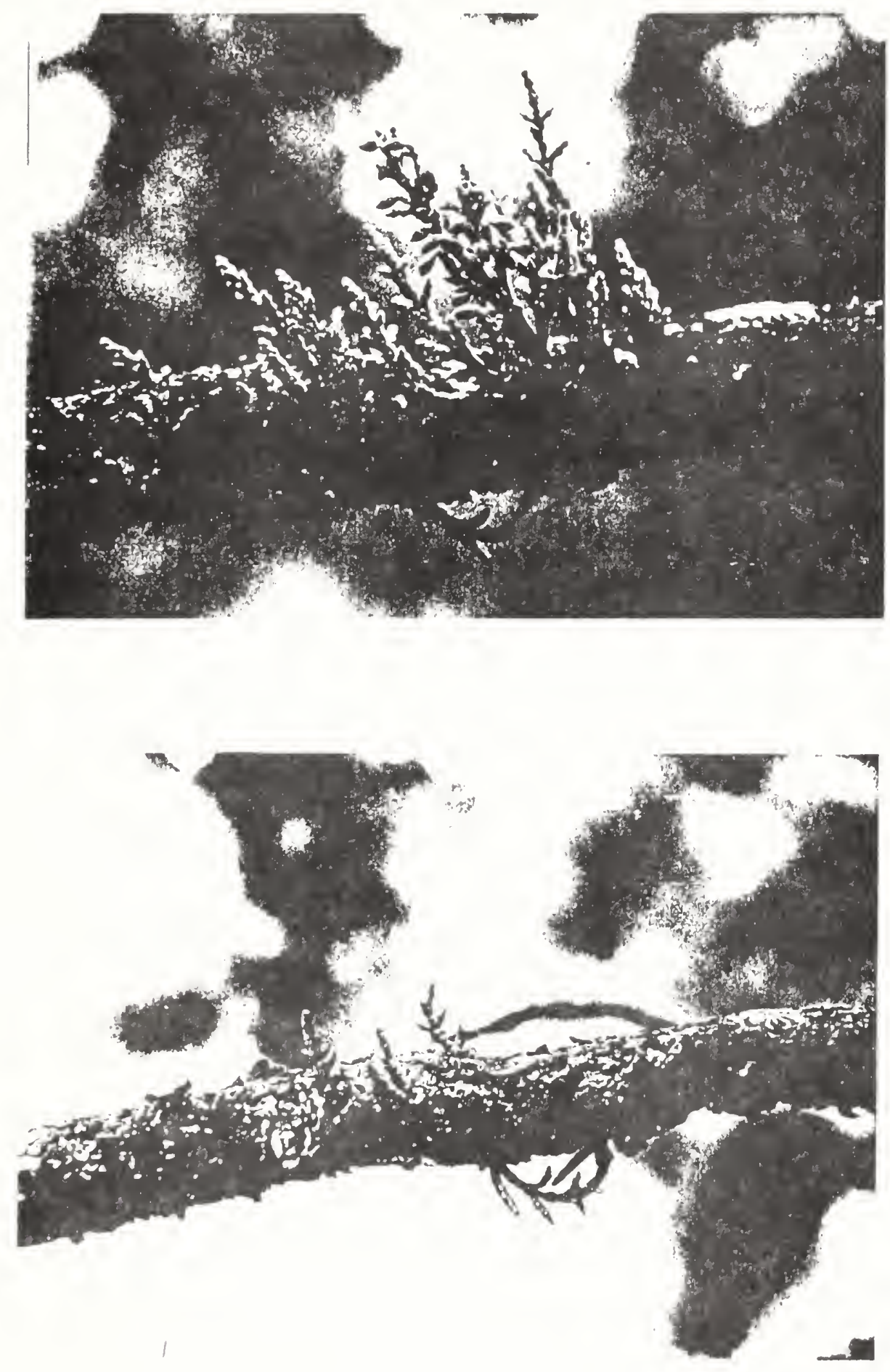

FICURE 5. Natural abscission of ponderosa pine dwarf mistletoe shoots on an infected branch before (upper) and five weeks later (lower). 

$\cdot$ 
$\cdot 1 \cdot .=$

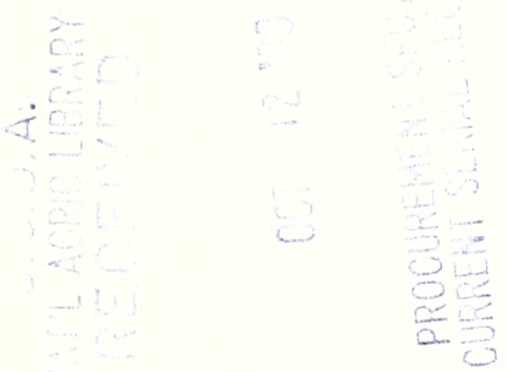

